\title{
Occupational Exposure to Blood and Body Fluids among Health Care Workers at Hospitals of Aksum Town, Tigray, Ethiopia: A Cross-Sectional Study
}

\author{
Ayehu Kassaw* and Biniyam Demisse \\ School of Nursing, College of Health Sciences, Aksum University, Aksum, Ethiopia
}

*Corresponding author: Ayehu Kassaw, School of Nursing, College of Health Sciences, Aksum University, Aksum, Ethiopia

\begin{abstract}
Background: Health care workers face a daily risk of occupational exposure to blood and body fluids that makes susceptible them for pathogens at working areas. The most common pathogens are related with viruses like Hepatitis B, C and Human Immuno-deficiency Virus and bacteria's that are causing infections with chronic problems to even disabilities and deaths.

Purpose: The aim of this study is to assess the occupational exposure to blood and other body fluids and their associated factors among health care workers working in hospitals of Aksum town.

Methods: Facility based cross-sectional study was conducted from April 21 to May 21, 2019. A total of 219 participants were selected for the study using simple random sampling technique. To collect the data, a structured questionnaire was used. Then collected data was entered in to SPSS version 23 software packages for analyzing the data on the bivariable and multivariable logistic regression model. The degree of association between dependent and independent variables were assessed using the odds ratio and $95 \%$ confidence interval, and variables with a p-value < 0.05 was considered as significant.
\end{abstract}

Results: The study revealed that $53.88 \%$ of health care workers had experienced occupational exposure to blood and other body fluids. Those health care workers who had more work experience had a more chance of exposure (AOR 4.74 (1.99-9.87)). Nurses are more than fivefold to be exposed than physicians. Those health care workers, who didn't wear gloves during procedure, had 2.02 times more exposure to blood and other body fluids than those who wore gloves during procedures (AOR 2.02, 95\% (Cl 1.02-3.31)).

Conclusion: Magnitude of occupational exposure was high among healthcare workers. These exposures of health care workers to blood and body fluids were determined by the availability of personal protective equipment in the health facilities, training on infection prevention, infection prevention methods with in the hospital and compliance with guidelines.

\section{Keywords}

Body fluid, Blood, Health professionals, Occupational exposure, Ethiopia

\section{List of Abbreviations}

AKUCSH: Aksum University Comprehensive Specialized Hospital; BBFs: Blood and Body Fluids; HCWs: Health Care Workers; HIV: Human Immunodeficiency Virus; PPEs: Personal Protective Equipment; SPs: Standard Precautions; UP: Universal Precaution

\section{Introduction}

Occupational exposure to blood and other body fluids (BFFs) is a daily risk faced by health care workers $\left(\mathrm{HCWs}^{\prime}\right)$. They are the most commonly exposed groups to pathogens that can transmitted by bacteria and viruses like Hepatitis B, Hepatitis C and Human Immuno-Deficiency Virus [1]. The exposure to blood and body fluids affects the safety and wellbeing of health care workers and compromise the overall quality of the health care delivery system as well. Health care workers also face significant level of fear, emotional distress, and anxiety that may result in critical changes in occupational behavior [2].

Exposure to blood and other body fluids (BFFs) is significantly reduced by universal precaution (UP)

Citation: Kassaw A, Demisse B (2021) Occupational Exposure to Blood and Body Fluids among Health Care Workers at Hospitals of Aksum Town, Tigray, Ethiopia: A Cross-Sectional Study. Int Arch Nurs Health Care 7:166. doi.org/10.23937/2469-5823/1510166

Accepted: September 28, 2021: Published: September 30, 2021

Copyright: (c) 2021 Kassaw A, et al. This is an open-access article distributed under the terms of the Creative Commons Attribution License, which permits unrestricted use, distribution, and reproduction in any medium, provided the original author and source are credited. 
measures but, there is still a high prevalence of injuries to needle stick, cuts and splashes of patients' body fluids among health care workers. These exposures cause them susceptible to infections including HIV and other pathogens. Those who work in the operating, delivery, emergency, laboratory and intensive care units have an increased risk for the exposures $[3,4]$.

Worldwide, occupational exposure of health care workers to blood and body fluids posing a major health care problem. A study revealed that from 35 million HCWs, more than $8 \%$ of them are exposed to bloodborne pathogens [4]. In another reviewed article, more than half of study participants had occupational exposure to BBFs [5].

The magnitude of occupational exposure to BBFs in developing countries ranges from $1.8 \%$ to $5.8 \%$. Factors associated with this exposures were related with prolonged working hours, work experience, lack of education and training programs, lack of personal protective equipment's (PPEs) and suboptimal compliance to universal precautions (UPs) $[6,7]$.

In Ethiopia, there is paucity of data regarding the national burden of health care workers exposure to blood and body fluids. In some studies that are done in the country, there is low self-reporting of HCWs' toward exposure. But, the number of HCWs having had sharps injury and BBFs exposure was still high $[8,9]$. Despite the international and national burden of the problem, there is no previous study was conducted in our study settings. Therefore, the aim of this study was to assess the occupational exposure of health workers to blood and body fluids and their associated factors among health care workers in hospitals of Aksum city.

\section{Methods and Materials}

\section{Study area and period}

A facility based cross-sectional quantitative study design was conducted on health care workers in Aksum University Comprehensive Specialized Hospital (AKUCSH) and St. Mary Hospitals of Aksum Town, Tigray Regional State, North Ethiopia from April 21 to May 21/2019.

\section{Participants}

All fulltime health care workers, from hospital units and with at least 6-month experience in their current hospital were included in the study. Proportional allocation of the sample size for the hospitals was done to select 219 participants. Then simple random sampling technique was conducted to each hospital by using the list of professionals as a sampling frame.

\section{Data collection procedures}

Six trained data facilitators, two supervisors and principal investigator were participated for the successful completion of the study. They had a minimum of BSc degree in the field of health sciences. The selfadministered questionnaires were distributed for the study participants.

The data collection tool has three parts that contains questions on socio-demographic information, questions on awareness about training on infection prevention and utilization personal protective equipment's (PPE) and questions on occupational exposure to blood and body fluids.

\section{Data analysis procedures}

The data was entered into EpiData version 3.1 and analyzed using statistical software package for social science students SPSS V. 23.0. Descriptive statistics was used to describe the sociodemographic characteristics of participants, training on infection prevention and utilization personal protective equipment's and occupational exposure to blood and body fluids. Bivariable logistic regression analysis were used to determine level of association between independent and outcome variable and those variables with $P$ value $<0.25$ were entered to multivariable logistic regression analysis to identify association and control confounding variable. Variables with $\mathrm{P}$-value of $<0.05$ at $95 \% \mathrm{Cl}$ were considered as statistically significant. Then finally the data was displayed by using texts, and tables.

\section{Data quality management}

Training was given for supervisors and data collectors on the objectives of the study, the contents of the questionnaire, issues related with keeping confidentiality of the responses and the rights of respondents to proceed or to refuse. Pre-test was done at Suhul Hospitals (nearby hospital) and necessary modifications were made. During data collection period, follow up and supervision was conducted by the investigators and continuous support was given to participant at the time of difficulty. Principal investigator and data collectors checked collected data every day at the end of each data collection day.

\section{Ethical consideration}

Primarily, ethical clearance was obtained from Aksum university health science college and comprehensive specialized hospital department of nursing (with approval number: AKUCHS/RSH/0121/19). Official letters of cooperation were obtained from the university to the hospital and brief explanation about the purpose of the study was given to the hospital administration. After getting permission from hospital administration, participants consent was obtained after a brief explanation of why they were taking part in the research before conducting the study. To maintain confidentiality, name of the participants was not disclosed and the data was collected by filling self-administration questioners. Anyone not willing to take part in the study was given full right to withdrawn from the study. 
Table 1: Socio-demographic characteristics of HCWs in hospitals of Aksum town, Aksum, Tigray, Ethiopia, 2019.

\begin{tabular}{|c|c|c|}
\hline \multicolumn{2}{|l|}{ Variables } & \multirow{2}{*}{\begin{tabular}{|l} 
Frequency (\%) \\
$20(10)$
\end{tabular}} \\
\hline Age (years) & $<25$ & \\
\hline & $25-30$ & $142(71)$ \\
\hline & $31-35$ & $27(13.5)$ \\
\hline & $36-40$ & $8(4)$ \\
\hline & $41-45$ & $1(0.5)$ \\
\hline & $>45$ & $2(1)$ \\
\hline \multirow[t]{2}{*}{ Sex } & Male & $140(63.93)$ \\
\hline & Female & 79 (36.07) \\
\hline \multirow[t]{2}{*}{ Marital status } & Married & 109 (49.77) \\
\hline & Single & $110(50.23)$ \\
\hline \multirow[t]{3}{*}{ Religion } & Orthodox & $179(81.74)$ \\
\hline & Muslim & $28(12.79)$ \\
\hline & Protestant & $12(5.48)$ \\
\hline \multirow[t]{5}{*}{ Job category } & Nurse & $140(63.93)$ \\
\hline & Midwife & $30(13.70)$ \\
\hline & Lab tech. & $12(5.48)$ \\
\hline & Anesthesia & $4(1.83)$ \\
\hline & Physician & $33(15.07)$ \\
\hline \multirow{5}{*}{$\begin{array}{l}\text { Educational } \\
\text { Qualification }\end{array}$} & Diploma & $14(6.39)$ \\
\hline & BSc & $163(74.43)$ \\
\hline & MSc & $9(4.11)$ \\
\hline & GP & $25(11.42)$ \\
\hline & Specialist & $8(3.65)$ \\
\hline \multirow[t]{3}{*}{ Work experience } & $\leq 1$ year & $34(15.52)$ \\
\hline & $2-5$ years & $154(70.31)$ \\
\hline & $\geq 6$ years & $31(14.15)$ \\
\hline
\end{tabular}

\section{Results}

\section{Socio-demographic characteristics}

A total of 219 health care workers were participated in the study from both AKUCSH and St. Merry hospitals. From them, 140 (63.93\%) were males, 155 (70.78\%) of the study participants were fall in range between 25-30 years, 164 (74.89\%) of participants were BSc degree holders, 25 (11.42\%) were general practitioners. Regarding with job category of the HCWs, 137 (62.56\%) were nurses, 32 (14.61\%) physicians and 34 (15.53\%) were midwifes. $70.31 \%$ of health care workers have a 2-5 years of work experience (Table 1 ).

\section{Training on infection prevention and the use of personal protective equipment (PPE)}

In this study more than fifty percent of the study participants had reported as there is enough PPEs throughout the year and 208 (94.98\%) were aware of and concerned about exposures and injuries following exposures. 119 (54.34\%) use consistently PPE while 113 (51.60\%) had taken training on occupational infection prevention. $52.97 \%$ participants were reported that there
Table 2: Infection Preventions (IPs) and use of personal protective equipment (PPE) at hospitals of Aksum town, Aksum, Tigray, Ethiopia, 2019.

\begin{tabular}{|l|l|l|}
\hline Variables & & Frequency (\%) \\
\hline Availability of personal protective & Yes & $123(56.16)$ \\
\cline { 2 - 3 } equipment throughout the year & No & $96(43.84)$ \\
\hline Awareness about exposure and & Yes & $208(94.98)$ \\
\cline { 2 - 3 } the impact of the resulting injuries & No & $11(5.02)$ \\
\hline Training on infection preventions & Yes & $113(51.60)$ \\
\hline and standard precautions & No & $106(48.40)$ \\
\hline \multirow{2}{*}{$\begin{array}{l}\text { Use of personal protective } \\
\text { equipment's }\end{array}$} & Yes & $119(54.34)$ \\
\hline $\begin{array}{l}\text { Availability of hand washing } \\
\text { basins in the department/unit }\end{array}$ & No & $100(45.66)$ \\
\hline Hand washing practice before and & Yes & $163(74.43)$ \\
\cline { 2 - 3 } after doing any procedure & No & $52(25.57)$ \\
\hline $\begin{array}{l}\text { Infection prevention methods in } \\
\text { the hospital }\end{array}$ & Yes & $116(52.97)$ \\
\hline & No & $103(47.03)$ \\
\hline
\end{tabular}

are enough infection prevention protocols in the hospital they work in. Almost $74.43 \%$ of the study participants reported the presence of enough hand washing materials at their working department and $68.86 \%$ washed their hands between procedures (Table 2).

\section{Exposure to blood and body fluids}

In this study, 118 (53.88\%) of respondents have occupationally exposed to either blood splash or fluid splash on their body and $19.49 \%$ of those exposures occurred before one year and $20.34 \%$ of exposures occurred before 3 years. A total of 77 (35.16\%) and 53 (24.20\%) of respondents had been exposed to blood splashes and fluid splashes respectively. From exposed to fluid splash, $15.01 \%$ were exposed to urine, faces, penile/vaginal discharge and $8.68 \%$ exposed to amniotic fluid (Table 3).

\section{Factors associated with occupational exposure to blood and body fluids}

Those variables shown significant association on bivariate analysis were entered into multivariate logistic regressions model. Health care works' experiences, type of occupation, not donning gloves during procedures and failure to complying with standard producers, were variables which showed significant association with occupational exposure to BBFs. Those health care workers who had work experience of more than six years had more exposed than those who had less than two years of work experience (AOR, 4.74 (1.99-9.87)). Nurses are more than fivefold to be exposed than physicians. Those health care workers who didn't wear gloves during procedure had 2.02 times more exposed to blood and other body fluids than those who wore gloves during procedures (AOR 2.02 (1.02-3.31)) (Table 4). 
Table 3: Prevalence of occupational exposure to blood and other body fluids among HCWs at hospitals of Aksum town, Tigray, Ethiopia, 2019.

\begin{tabular}{|c|c|c|}
\hline Variables & & Frequency (\%) \\
\hline \multirow{2}{*}{$\begin{array}{l}\text { Exposure to BBFs while doing or assisting } \\
\text { procedures }\end{array}$} & Yes & $118(53.88)$ \\
\hline & No & $101(46.12)$ \\
\hline \multirow[t]{4}{*}{ Frequency of exposure } & $\leq 1$ time & $23(19.49)$ \\
\hline & 2-3 time & $71(60.17)$ \\
\hline & 4-5 time & $20(16.95)$ \\
\hline & $\geq 6$ time & $4(3.39)$ \\
\hline \multirow[t]{4}{*}{ Type of exposure } & Fluid splashing & $53(24.20)$ \\
\hline & Blood splashing & $77(35.16)$ \\
\hline & Needle stick injury & $33(15.07)$ \\
\hline & Cut (surgical blade) & $24(10.96)$ \\
\hline \multirow[t]{4}{*}{ Type of fluid exposed } & Amniotic fluid & $19(8.69)$ \\
\hline & Pleural fluid & $3(1.37)$ \\
\hline & Peritoneal fluid & $4(1.83)$ \\
\hline & Urine, faces, penile/vaginal discharge & $33(15.01)$ \\
\hline \multirow[t]{8}{*}{ Working area where exposure occurs } & Medical ward & $28(12.79)$ \\
\hline & Surgical ward & $43(19.63)$ \\
\hline & Pediatric ward & $20(9.13)$ \\
\hline & Operation room & $12(5.48)$ \\
\hline & Emergency room & $16(7.31)$ \\
\hline & OPD & $3(1.37)$ \\
\hline & Gynecological ward & $22(10.05)$ \\
\hline & Laboratory room & $4(1.83)$ \\
\hline
\end{tabular}

Table 4: Factors associated with occupational exposure to blood and body fluids among HCWs at hospitals of Aksum town, Tigray, Ethiopia, 2019.

\begin{tabular}{|c|c|c|c|c|c|}
\hline \multirow[t]{2}{*}{ Variables } & & \multicolumn{2}{|c|}{$\begin{array}{l}\text { Occupational } \\
\text { Exposure }\end{array}$} & \multirow[t]{2}{*}{$\begin{array}{l}\text { Crude OR } \\
(95 \% \mathrm{Cl})\end{array}$} & \multirow[t]{2}{*}{ Adjusted OR (95\% Cl) } \\
\hline & & Yes & No & & \\
\hline \multirow[t]{2}{*}{ Sex } & Male & 102 & 38 & $0.80(0.76-1.99)$ & \\
\hline & Female & 45 & 34 & 1.00 & \\
\hline \multirow[t]{4}{*}{ Age group } & $<25$ & 11 & 6 & $3.11(0.34-5.16)$ & \\
\hline & $25-30$ & 106 & 36 & $0.55(0.21-1.01)$ & \\
\hline & $31-35$ & 22 & 15 & $0.83(0.75-2.11)$ & \\
\hline & $>35$ & 11 & 9 & 1.00 & \\
\hline \multirow{3}{*}{$\begin{array}{l}\text { Working experience } \\
\text { (years) }\end{array}$} & $\leq 2$ year & 21 & 13 & 1.00 & 1.00 \\
\hline & $2-5$ years & 97 & 57 & $1.22(0.47-1.88)$ & \\
\hline & $\geq 6$ years & 18 & 13 & $5.26(2.43-8.64)$ & $4.74(1.99-9.87)^{\star}$ \\
\hline \multirow[t]{5}{*}{ Occupation (profession) } & Nurse & 110 & 30 & $5.03(1.34-20.99)^{\star}$ & $11.3(1.48-90.0)^{*}$ \\
\hline & Midwife & 21 & 9 & $2.01(0.42-1.33)$ & \\
\hline & Lab tech. & 10 & 2 & $1.04(0.22-1.34)$ & \\
\hline & Physician & 14 & 19 & 1.00 & 1.00 \\
\hline & Anesthesia & 1 & 3 & $0.53(0.16-1.87)$ & \\
\hline \multirow[t]{5}{*}{ Work department } & Medical ward & 20 & 8 & 1.00 & \\
\hline & Surgical ward & 64 & 29 & $0.64(0.42-2.61)$ & \\
\hline & Pediatric ward & 11 & 9 & $0.88(0.35-1.72)$ & \\
\hline & Operation room & 5 & 7 & $1.11(0.34-1.79)$ & \\
\hline & Emergency room & 35 & 31 & $1.30(0.12-5.03)$ & \\
\hline
\end{tabular}




\begin{tabular}{|l|l|l|l|l|l|}
\hline \multirow{2}{*}{ Shortage of PPE } & Yes & 104 & 19 & $1.75(1.09-2.79)$ & \\
\cline { 2 - 6 } & No & 56 & 40 & 1.00 & \\
\hline $\begin{array}{l}\text { Presence of hand } \\
\text { washing facilities }\end{array}$ & Yes & 107 & 16 & 1.00 & 1.00 \\
\hline & No & 78 & 18 & $1.80(1.22-2.85)^{*}$ & $2.02(1.02-3.31)^{*}$ \\
\hline $\begin{array}{l}\text { Gloving during last } \\
\text { procedure }\end{array}$ & Yes & 59 & 16 & 1.00 & 1.00 \\
\hline $\begin{array}{l}\text { Compliance with } \\
\text { guidelines }\end{array}$ & Nes & 107 & 37 & $2.01(1.31-3.03)^{*}$ & $2.04(1.06-3.41)^{*}$ \\
\hline $\begin{array}{l}\text { Work place safety for } \\
\text { IPs }\end{array}$ & Yes & 98 & 15 & 1.00 & \\
\hline
\end{tabular}

${ }^{*} p<0.0$

\section{Discussion}

In this study, $53.88 \%$ of HCWs had occupational exposure to blood and body fluids in their prior work experiences, which is nearly similar with a study conducted in the northern Ethiopia among six hospitals of $(56.3 \%)$ [8]. However, this prevalence is higher than the studies done in Kenya rift valley provincial hospital $(25 \%)$ and in Egypt $(32.75 \%)[10,11]$. And lower than the survey conducted in China (66.3\%) [12]. This difference in prevalence may be due to socio-demographic variations among study participants, work experience of $\mathrm{HCWs}$, the setting of health care system, PPE availability and access, and in-service trainings about occupational exposures [7].

A total of $35.16 \%$ and $24.20 \%$ of HCWs in this study reported that they had had blood splashes and fluid splashes respectively, this prevalence is lower than results from China (66.3\%) [12]. But this prevalence is higher than that of a study done in Kenya [10]. In this study needle stick injuries prevalence is comparable with the study conducted in the northern Ethiopia $(17.2 \%)$ and lower than the study conducted in eastern Ethiopia (30.5\%) and Nepal (70.2\%). Also cut (surgical blade) exposure is high in this study than conducted in Nepal (5\%). However, in this study the majority of occupational exposure to BBFs occurred at surgical wards 45 (19.63\%) and medical wards 28 (12.79\%) $[8,13,14]$.

\section{Conclusion}

The prevalence of occupational exposure to BBFs among health care workers in our study was high that more than half of the participants were exposed. Nurses were the most susceptible groups with a blood splash. The most procedures that predispose the occurrence were intravenous line securing and drawing of blood samples. Health care workers' experience, occupation types, failure to wear gloves during procedures, and failure to complying with standard precautions were the reasons for health care workers occupational exposure to blood and body fluids.

\section{Acknowledgement}

The authors acknowledge Aksum University Health Science College and School of Nursing for their cooperation. We would like to thank respondents, data collectors, supervisors, health care workers and hospital administrators for their valuable participation.

\section{References}

1. El-Sokkary RH, Tash RME, Meawed TE, El seifi OS, Mortada EM (2017) Detection of hepatitis C virus (HCV) among health care providers in an Egyptian university hospital: Different diagnostic modalities. Infect Drug Resist 10: $357-364$

2. Mabwe P, Kessy AT, Semali I (2017) Understanding the magnitude of occupational exposure to human immunodeficiency virus (HIV) and uptake of HIV postexposure prophylaxis among healthcare workers in a rural district in Tanzania. J Hosp Infect 96: 276-280.

3. Tabatabaei SM, Pour FB, Avval JO, Osmani S, Mokhtari $S$ (2016) Occupational exposure to blood and other body fluids among healthcare workers in three teaching hospitals, Southeast Iran. Int J Infect 3: e32879.

4. Nwaiwu CA, Egro FM, Smith S, Harper JD, Spiess AM (2017) Seroconversion rate among health care workers exposed to HIV-contaminated body fluids: The University of Pittsburgh 13-year experience. Am J Infect Control 45: 896-900.

5. Serdar T, Đerek L, Unic A, Marijancevic D, Markovic D, et al. (2013) Occupational exposures in healthcare workers in University Hospital Dubrava-10 year follow-up study. Cent Eur J Public Health 21: 150-154.

6. Auta A, Adewuyi EO, Tor-Anyiin A, Aziz D, Ogbole E, et al. (2017) Health-care workers' occupational exposures to body fluids in 21 countries in Africa: Systematic review and meta-analysis. Bull World Health Organ 95: 831-841.

7. Kimaro L, Adinan J, Damian DJ, Njau B (2018) Prevalence of occupational injuries and knowledge of availability and utilization of post exposure prophylaxis among health care workers in Singida District Council, Singida Region, Tanzania. PLoS One 13: e0201695.

8. Yasin J, Fisseha R, Mekonen F, Yirdaw K (2019) Occupational exposure to blood and body fluids and associated factors among health care workers at the University of Gondar Hospital, Northwest Ethiopia. Environ Health Prev Med 24: 18.

9. Alemayehu T, Worku A, Assefa N (2016) Sharp injury and exposure to blood and body fluids among health care 
workers in health care centers of Eastern Ethiopia. Int $\mathrm{J}$ Occup Env Med 7: 172-180.

10. Mbaisi EM, Ng'ang'a Z, Wanzala P, Omolo J (2013) Prevalence and factors associated with percutaneous injuries and splash exposures among health-care workers in a provincial hospital, Kenya, 2010. Pan Afr Med J 14: 10.

11. Salama O, Elweshahi H, Abd El Raheem A (2017) Knowledge, attitudes and compliance with hand hygiene practices among health care workers in Alexandria Main University Hospital. Journal of High Institute of Public Health 47: 39-47.
12. Zhang M, Wang H, Miao J, Du X, Li T, et al. (2009) Occupational exposure to blood and body fluids among health care workers in a general hospital, China. Am J Ind Med 52: 89-98.

13. Bhattarai S, Smriti KC, Pradhan PMS, Lama S, Rijal S (2014) Hepatitis B vaccination status and needle-stick and sharps-related injuries among medical school students in Nepal: A cross-sectional study. BMC Res Notes 7: 774.

14. Yenesew MA, Fekadu GA (2014) Occupational exposure to blood and body fluids among health care professionals in Bahir Dar town, Northwest Ethiopia. Saf Health Work 5: 17-22. 